\title{
Empowering Women in Independent Household Waste Management towards Smart Environment in Magelang City
}

\author{
Joko Tri Nugraha ${ }^{1}$, Retno Sunu Astuti ${ }^{2}$ \\ \{jokotrinugraha@students.undip.ac.id ${ }^{1}$ \} \\ Universitas Diponegoro, Indonesia ${ }^{1,2}$
}

\begin{abstract}
The increasing number of household waste, without proper mitigation, is able to trigger global warming. One of the efforts to mitigate threats to people's welfare from numerous disease factors is the management of household waste into beneficial and environment-friendly material. Legok Makmur is the first organic village in Magelang City. It began by participating in the socialization and mentoring from Non-Government Organizations engaged in the field of environmental health, the household waste and management organic village movement, involved only 20 households. The purpose this study are to analyze the empowerment activities of household waste management by the women in Legok Makmur Village; to analyze the factors that promoted the awareness of the women to participate in the program's to manage household and waste and; to formulate policy recommendations so that the women are able to improve their living environment's quality. The applied approach is qualitative descriptive with flow model analysis technique. Research site was in Legok Makmur Village, Magelang City. Data collection technique used interview, documentation, and observation. This research possesses a significant importance for it contributes to the discovery of the source of the issue of women empowerment program in Indonesia's urban area is not yet optimal.
\end{abstract}

Keywords: Empowerment, Organic Village, Smart Environment.

\section{Introduction}

The word "development" has been a frequent discussion among many communities: the bureaucrats, politicians, academicians, and practitioners, and groups of people who are concerned about and have interest in the efforts to improve the society's life and their own family. However, a development focalized to its growth attainment would cause disasters for most of the aforementioned society's life [1].

The benchmark of a successful development is regarded from two instances: first, high economic growth, and second, it is conducted continuously (without any occurrence of neither social nor natural damages). A growth-oriented development may also neglect environment issues threatening collective life. In fact, national and international media publicized the rise of air temperature leads to global warming. One of its causes is the rise of $\mathrm{CO}_{2}$ in the air as the result of industrialization and transportation sector.

In addition to the two cases above, global warming could also be triggered by the plethora of improperly processed household waste. One of the means to mitigating threats to mankind's 
welfare from multitude of pathological factors is independent recycling of household waste into beneficial and environment-friendly items. As Kampung (Village) Legok Makmur, Magelang City, has practiced. Legok Makmur is the first organic village in Magelang City. It all began with 20 households participating in socialization and counseling from NonGovernment Organization (NGO, LSM) in the fields of environment health, waste recycling movement, and organic village.

In spite of its small numbers of members, the organization has many activities. Aside from composting and organic agriculture in narrow fields, the women also conduct waste bank (bank sampah) and barter store (warung barter). Waste bank conducts organic and inorganic wastes sorting, such as plastic and paper, sold to collectors and the money goes to the treasury. Whilst in the barter store, everyone may bring their waste to the waste bank and barter it with the needed staple.

Notwithstanding, they also involve another villager, an artisan to create handicrafts from waste materials. Agricultural yields such as vegetables, fruits, new crop seeds, numerous processed foods from the harvested crops, and handicrafts eventually becomes commodities that are high in demand.

Having worked hard for a year, in 2013 Legok Makmur Village earned a grant which they invested to build poultry farm and catfish pond. Aside from being sold, the revenue is also used to provide for the villagers' needs for food. Therefore, the waste and environment aware movement progressed into productive economic business. Based on this background, the researchers are interested to observe women empowerment in independent household waste management in Magelang City.

The concept of empowerment emerged from two major premises; failure and hope. Failure in the context of the failed economic development models to overcome the issues of poverty and continuous environment. Meanwhile, hope arose because of the existence of development alternatives which includes democratic values, gender equality, cross-generation equality, and adequate economic growth. Failure and hope are not the indicator for the output of social sciences, instead they are the reflection of normative and moral values. Failure and hope will be highly palpable in individual and society level. In a wider scope what perceived are the symptoms of failure and hope. Hence, the essence of society empowerment is the collective value of individual empowerment [2].

The concept of empowerment is the result of interactive work process both in ideological and implementation levels. In the ideological level, the concept of empowerment is the end product of interaction between the concepts of top down and bottom up, between growth strategy and people-centered strategy. In the implementation level, interaction will take place through inter-autonomy confrontation. The concept of empowerment also contains a partiality concept for the people below the poverty line [3][4].

According to Sulistiyani [5], etymologically, empowerment is derived from the word "power" meaning power or ability. Based on said definition, empowerment could be interpreted as a process towards potential or a process to achieve potential, or power, or capability, or a process of giving potential/power/capability from the capable ones to the incapables. The definition of process refers to a series of actions or measures executed in chronologic systematic manner that reflects to the phasing of endeavors to evolve the society from lack in or yet to possess of capability into proficiency. Process will be referring to a concrete measure to evolve the deficient society in the terms of: knowledge, attitude, or practice (KAP) towards knowledge mastery, conscious attitude and decent skills.

The interpretation of achieving potential/power/capability refers to the origin of initiative to achieve or upgrade potential, power, or capability as to possess empowerment. The word 
"achieve" indicates that the source of initiative to empowerment came from the society itself. Thus, it is the society who seeks, strives for, executes, creates the situation, or requests to other parties to give achieving potential/power/capability. This type of climate will rise only if the society acknowledges their incapability/impotency/lack of power as well as awareness to the necessity of achieving potential/power/capability. Whereas the interpretation of the word "giving" refers that the origin of the initiative did not come from the society. The initiative to redirect potential/power /capability is other parties who possess power and capability, for example: the government and other development agents [5].

Pranarka [6] and Prijono [7] State that empowerment has two definitions. The first is to give power or authority The second is to give ability or enable. The interpretation of the former comprises of giving power, redirecting power or delegating authority to the party who are lack in or yet to possess power. On the other hand, the interpretation of the latter is giving capability or empowement along with giving opportunity to other parties to conduct something.

In contrast to Pranarka, Sulistiyani [5] and Sumodiningrat [8] opiniates "pemberdayaan", in fact is a term typical to Indonesia rather than the western countries. In the west, the term is translated as empowerment, and while correct, it's inaccurate. The empowerment in discussion is to give potency not power. Empowerment in the western term has more nuance in giving authority than the empowerment itself. The most accurate term would be energize or giving energy. Empowerment is giving energy so that the concerned people are capable to act independently.

In regards to the interpretation of society empowerment concept, [9] reveals that the essence of empowerment is comprised of three points: flourishing (enabling), developing potential (empowering), the creation of independence.

Hereafter, Sulistiyani [5], Miradj and S. Sumarno [10], Saugi and Sumarno [11] states that substantially, empowerment is the creation of atmosphere or climate that enables the society's potential to flourish (enabling). This logic is based on the assumption that there is not a single society that do not possess potential. Every society certainly possesses potential, however sometimes they are not aware or the potential itself is not explicitly known. Therefore, the potential must be unearthed and be developed. Should this assumption develops, then empowerment would be an effort to cultivate potential by encouraging, motivating, and raise the awareness to the potential they possess and strive to make it flourish.

Moreover, empowerment should not ensnare society into a trap of dependency (charity), empowerment, on the contrary must deliver to the process of independency. The core definitions obtained from empowerment discourse are: (1) Potency must be understood as a capability the society supposed to possess, so they may carry out something (independent development) and; (2) Empowerment is a gradual process that must be conducted in order to achieve and cultivate potential so that the society becomes independent [5].

\section{Research Method}

The applied method in this research is qualitative with study case approach. Data collection using in-depth interview, observation, and documentation. Validity technique using triangulation. Data analysis using flow model analysis. Miles and Huberman elucidate further three conducted activities: (1) Data reduction, which is the process of sorting, formulating, simplification and clarification of the data unfolded from the written notes on the field, that transpired continuously during the research; (2) Data presentation is a set of compiled 
information that provides the possibility of concluding inference and taking action, as well as; (3) Concluding inference or verification after data is collected, and hereafter analysed qualitatively [12].

\section{Result and Discussion}

\subsection{Empowering Phase}

Society empowerment is an effort to actualize the potential that the society has already possessed. Every socieaty in particular scope actually has economic potential to be developed. Said local economic potential if properly developed is not impossible will be able to allay poverty. Society empowerment requires an extensive process [13].

In accordance to the results of studies Suwarjo had conducted above, the research we conducted also discovered the same issue, concerning the independent household waste management practiced by the women in Legok Makmur Village. The output of our interview with the Head of Women Association for Intregated Waste Management shows that the villagers are beginning to be able to recycle wastes to simple crafts, namely compost, organic plants, and accessories bearing economic values [14][15].

Legok Makmur Village, Wates Sub-District (Kelurahan Wates), North Magelang (Kecamatan Magelang Utara, District) becomes the pioneer of organic village in Magelang City. The endeavor to management and reusing waste has been initiated by the local women since 2012. This creative business arose to reuse the waste to be more organized, considering that the local villagers have yet to pay full attention in this matter.

Wilson [16] stated that empowerment activity for each person in an organization is a cycle consisted of: (1) Cultivating the desire in one self to change and improve, is the starting point in the need of empowerment. Without the desire to change and improve, then all endeavors will not gain sympathy nor the society's participation; (2) Cultivating the will and courage to detach one self from comfort or obstacle they felt, and subsequently to decide participating in the empowerment to make the desired change and improvement a reality; (3) Developing the will to participate or take part in empowerment activities that contribute benefits or improvement (4) Increasing the role or participation in empowerment activities of which benefits and improvement has manifested; (5) Increasing the role and loyalty to the empowerment activities, aimed to motivation development to create change; (6) Improving the empowerment activities' effectivity and efficiency; (7) Upgrading the competency to create change by means of new empowerment activity.

In the first phase of concept [13] above, i.e, coming to awareness, this is also in accordance with the output of our interview with an employee in North Tidar Sub-District (Kelurahan Tidar Utara). The beginning of Legok Makmur Village in becoming an organic village started from assisting the activities of Family Prosperity Empowerment in Magelang City (PKK Kota Magelang). Transforming household waste into compost has been conducted in Magelang City since 2006 (at Paten Gunung, RW 11, Rejowinangun Selatan). However, they only relied on their inornate supplies. Thereafter, they promoted the movement widely so the people are willing to make compost, and that was all. They have yet to discern the importance of managing household waste.

Empowerment is a "process to become" not an "instant process". As a process, empowerment is comprised of three phases, i.e: discerning phase, enabling phase, and 
empowering phase [1][2]. The first phase is discerning. In here, the target of empowerment is given education that they have the right to own something. For example, the target is the impoverished society. They are given knowledge that they could be wealthy, and it can be realized if they have the capability to arise from their poverty.

The programs conducted in this phase e.g: giving cognitive, belief, and healing knowledge. Essentially is to bring the targets to understand that they need to (build demand) be empowered and the empowering process begins from themselves (not from other people).

In line with the opinion above, Totok \& Soebiato [1] and Wrihatnolo et al [2] the phase of bringing people to discern the importance of househols management was inspired from one of Institution of Social Society Mentoring (Lembaga Pembinaan Sosial Masyarakat, LPSM) Bina Daya Kasih in Magelang City focusing and is active in environment field, its chairperson is Drs. Fance Oiholorin.

After coming to awareness, the second phase is enabling phase. This is what on daily basis we call as capacity building, or in a simpler language, enabling. To be given capability or potential, first and foremost, the targets must be capable. For example, before assigning regional autonomy, the recipient regions must endure capacity building to render them skillfull in managing the assigned autonomy. The process of capacity building is consisted of three kinds: manpower, organization, and grading system.

Human enabling in the context of rendering them capable, both as an individual and within a team. We are not unfamiliar with this concept since we frequently hold trainings, workshops, etc. The core meaning of enabling is to give capabilities to individuals or a group of people so that they are able to receive the given potential or power. Related to this human enabling, the women of RT 01 Legok Makmur Village has experienced mentoring from LPSM Bina Daya Kasih.

From the output of our interview, we sensed the people of Legok Makmur Village's vigor to manage their wastes independently. Organization enabling is executed by restructuring the organization that will be enabled. For instance, before receiving business opportunity, villagers-owned enterprise was established for the impoverished cluster. We have to admit that, this type of enabling is rare in occurrence because we oft to taking it for granted, thinking that "the organization will be enabled by default if the manpower is enabled, anyways". Every now and then, this premise is true, yet on the field, it isn't. The women in Legok Makmur Village also conduct organization enabling. The principles of the organic village activity came from the deca-housestead (dasa wisma) that was established on March 2012, consisted of 20 people.

The third enabling is the grading system. After the manpower and the establishment, now it is the grading system's turn. The grading system is the guideline. In organizational scope, grading system is related to Bylaw and Statutes, system and procedure, union regulations, etc. On a higher level, grading system is also comprised of organization culture, ethiquettes, and good governance. Grading system enabling is executed by assisting the target and creating a guideline among themselves. Regarding the grading system, the women of Legok Makmur Viillage are also capable of managing their spare time for activities benificial to the environment and their family.

The third phase is the giving of potential itself or empowerment in narrow interpretation. During this phase, the targets are given potential, power, authority, ot opportunity, according to their quality of capability. In the beginning, the women's activity were nothing but recycling their household waste into simple handicrafts, however, they have developed. This development was made a reality by distributing THR (Religious Holiday Allowance) up to Rp 400.000 ,- and ginger syrup to the association members. Up to this day, their 8 million rupiahs 
treasury is utilized for circulation and loan and saving activities. Also, in the household waste bank, the villagers can create savings and barter their wastes with the daily needs [17].

The essence of society empowerment is the process of increasing the society's awareness itself. One of the aspects is the opening of opportunities for actions towards improvement. The increase of awareness can be achieved with several strategies, among them: policies and planning, social actions and politics, as well as education and mentoring.

\subsection{Driving Factor}

Society empowerment efforts in Legok Makmur Village is necessary to develop their capabilities. Since it is the society who knows better about their needs, potential, and the resources they have. The main approach in empowerment concept is that the society is not the object of numbers of development project, but the subject of the efforts itself. In environment perspective, empowerment is inteded so that every person gains awareness, capability, and concern to secure and preserve natural resources and their continual management, and society empowerment program is a process that requires time. The results of our research in Legok Makmur Village, the society's participation in household waste management movement is driven by several factors, such as:

a) The mentoring organization is an active LPSM and well-known by the people in Magelang City. Thanks to the LPSM's contribution, the women in Legok Makmur Village has learnt to reuse their wastes, as composts, cultivating plants, and organic vegetables.

b) The household management movement contributed direct benefits to Legok Makmur Village's society, e.g: they now are able to save funds or barter wastes in the waste bank.

c) The obtained benefits in waste management are capable of providing the local's needs, several of them being: the neighborhood becomes more beautiful, increasing the locals' income, and giving them healthier life by consuming organic vegetables cultivated around the neighborhood.

d) A collective control conducted by the society, namely the Association of Waste Managing Women.

\section{Conclusion}

a) Women empowerment in household waste management in Legok Makmur Village is yet to be effective, several instances that requires attention are the supporting capabilities of the society's, the organizations, as well as characteristics.

b) The driving factor for women to participate in household waste movement i.e: (1) the mentoring organization is well-known; (2) The household waste management movement contributed direct benefits to the society; (3) The obtained benefits are able to cover the locals' needs and; (4) A collective control conducted by the villagers.

c) The women's innovation in household waste management renders women having vital role in environment management and is in accordance with the Mayor's vision and mission via organic village development. 


\section{References}

[1] M. Totok and Poerwoko Soebiato, Pemberdayaan Masyarakat dalam Perspektif Kebijakan Publik. 2019.

[2] R. N. Wrihatnolo, Randy R.; Dwidjowijoto, "Manajemen Pemberdayaan Sebuah Pengantar dan Panduan Untuk Pemberdayaan Masyarakat," Empower. Manag. An Introd. Guidel. to Soc. Empower., 2007.

[3] Mubyarto, Ekonomi Rakyat Program IDT dan Demokrasi Indonesia. Yogyakarta: Aditya Media Publication, 1997.

[4] B. Mubyarto; Soeradji, Gerakan Penanggulangan Kemiskinan, Laporan Penelitian di DaerahDaerah. Yogyakarta: Aditya Media, 1998.

[5] A. T. Sulistiyani, Kemitraan dan model-model pemberdayaan. Gava Media, 2004.

[6] A. M. W. Pranarka, Pemberdayaan: konsep, kebijakan, dan implementasi. Centre for Strategic and International Studies, 1996.

[7] O. S. Prijono and A. M. W. Pranarka, Pemberdayaan: Konsep, kebijakan, dan implementasi. Centre for Strategic and International Studies, 1996.

[8] G. Sumodiningrat, Pembangunan daerah dan pemberdayaan masyarakat: kumpulan esei tentang penanggulangan kemiskinan. Bina Rena Pariwara, 1996.

[9] T. Winarni, "Memahami Pemberdayaan Masyarakat Desa Partisipatif dalam Orientasi Pembangunan Masyarakat Desa Menyongsong Abad 21: Menuju Pemberdayaan Pelayanan Masyarakat," Yogyakarta: Aditya Media, 1998.

[10] S. Miradj and S. Sumarno, "Pemberdayaan masyarakat miskin, melalui proses pendidikan nonformal, upaya meningkatkan kesejahteraan sosial di Kabupaten Halmahera Barat," JPPM (Jurnal Pendidik. dan Pemberdaya. Masyarakat), vol. 1, no. 1, pp. 101-112, 2014.

[11] W. Saugi and S. Sumarno, "Pemberdayaan perempuan melalui pelatihan pengolahan bahan pangan lokal," JPPM (Jurnal Pendidik. dan Pemberdaya. Masyarakat), vol. 2, no. 2, pp. 226238, 2015.

[12] M. B. Miles and A. M. Huberman, "Analisis Data Kualitatif.” Jakarta: UI press, 1992.

[13] Suwarjo, "Penerapan Model Program Pemberdayaan Masyarakat di Kota Yogyakarta," J. Popul., vol. 5, no. 1, 2014.

[14] E. Duflo, "Women empowerment and economic development," J. Econ. Lit., vol. 50, no. 4, pp. 1051-1079, 2012.

[15] S. G. BURCEA, "The economical, social and environmental implications of infomal waste collection and recycling," Theor. Empir. Res. urban Manag., vol. 10, no. 3, pp. 14-24, 2015.

[16] J. Ife and F. Tesoriero, "Community development: Alternatif pengembangan masyarakat di era globalisasi,” Yogyakarta: Pustaka Pelajar, vol. 265, 2008.

[17] B. McAllister, Lucy; Magee, Amanda; Hale, "Women, E-Waste, and Technological Solutions to Climate Change," J. Heal. Hum. Rights, vol. 16, no. 1, pp. 166-178, 2014. 